\title{
PERAN GURU PENDIDIKAN KEWARGANEGARAAN DALAM MEMBANGUN KARAKTER KEPEMIMPINAN PESERTA DIDIK
}

\author{
Arsali $^{1}$ Aryanti Dwi Untari \\ Universitas Banten Jaya \\ Serang, Indonesia \\ arsalisali5@gmail.com ${ }^{1}$, aryantidwiuntari@unbaja.ac.id ${ }^{2}$
}

\begin{abstract}
This study aims to determine how the professionalsm of teachers in increasing the learning motivation of grade VII D student in MTs Al-Khairiyah Pipitan. the research method used is descriptive analysis research with a qualitative approach. Date collection techniques used by researchers in this study are through observation, interviews and documentation. The source of data in this qualitative research is the information directly from sources of information that are consideret to be related to the professionalism of PPKn teacher in MTs Al-Khairiyah Pipitan.The results of the study showed that the professionalsm of the teachers of PPKn at MTs Al-Khairiyah pipitan had specialized expertise by an expertise or specialization education program. have the ability to understand students. the ability to develop learning outcomes assessment tools and the learning process. Based on the results of research that PPKn teacher professionalsm offorts to improve student motivation by giving number/prizes, prizes, rivals/competitions, and giving tests.
\end{abstract}

Keywords: Teacher's role, citizenship education, leadership character.

\section{PENDAHULUAN}

Pendidikan merupakan sebuah proses pemindahan nilai-nilai yang dimiliki oleh manusia satu kepada manusia lainnya dalam suatu masyarakat. Proses pemindahan nilai itu dapat dilakukan dengan berbagai cara, diantaranya, melalui pengajaran, yaitu proses pemindahan nilai berupa (ilmu) pengetahuan dari seorang guru kepada murid atau murid-muridnya dari suatu generasi kegenerasi berikutnya. (Mohammad Daud Ali 2009:137). Salah satu komponen yang terpenting dalam pendidikan adalah guru, tugas dan peran seorang guru tidak hanya sebagai pengajar, namun memiliki peran yang sangat besar untuk mencapai keberhasilan proses pembelajaran. Peran guru profesional sangat besar kontribusinya dalam melaksanakan proses belajar di dalam kelas, setidaknya akan membentuk sikap siswa dalam belajar,dan bagi guru sendiri ialah sebagai alat untuk mencapai tujuan pembelajaran. Keberhasilan proses pembelajaran merupakan suatu harapan,baik guru maupun siswa, salah satu faktor yang dijadikan ukuran keberhasilan dalam proses pembelajaran 
adalah perubahan prilaku siswa dalam minat belajar siswa yang tinggi.

Kompetensi professional menurut Usman (2014: 45) meliputi (1) penguasaan terhadap landasan kependidikan, dalam kompetensi ini termasuk (a) memahami tujuan pendidikan, (b) mengetahui fungsi sekolah dimasyarakat (c) mengenal prinsip-prinsip psikologi pendidikan; (2) menguasai bahan pengajaran, artinya guru harus memahami dengan baik materi pelajaran yang diajarkan; (3) kemampuan menyusun program pengajaran, mencakup kemampuan menetapkan kompetensi belajar, mengembangkan bahan pelajaran dan mengembangkan strategi pembelajaran; (4) kemampuan menyusun perangkat penilaian hasil belajar dan proses pembelajaran.

Motivasi belajar menjadi faktor yang dapat mempengaruhi efektivitas pembelajaran. Motivasilah yang mendorong siswa ingin melakukan kegiatan belajar. Salah satu peran guru yaitu sebagai motivator, disinilah peran guru dibutuhkan guna meningkatkan motivasi siswa. (Djamarah, 2011, hlm.52) Siswa yang belajar dengan motivasi dapat melaksanakan semua kegiatan belajarnya dengan sungguh-sungguh dan penuh gairah. Sebaliknya siswa yang belajar dengan motivasi yang lemah, akan malas bahkan tidak mau mengerjakan tugastigas yang berhubungan dengan pelajaran. Kuat lemahnya motivasi belajar siswa turut mempengaruhi keberhasilannya. Oleh karena itu, motivasi belajar perlu diusahakan terutama yang berasal dari dalam diri dengan cara senantiasa memikirkan masa depan yang penuh tangtangan dan harus dihadapkan untuk mencapai cita-cita dan senantiasa memasang tekad bulat, selalu optimis bahwa cita-cita dapat dicapai dengan belajar. (Dalyono, 2015, hlm.57)

Minat mempunyai pengaruh yang besar terhadap aktivitas belajar siswa. Siswa yang memiliki minat terhadap mata pelajaran Pendidikan Pancasila dan Kewarganegaraan (PPKn), maka siswa akan mempelajarinya dengan sungguhsungguh. Hal ini dapat dilihat seperti rajin belajar, merasa senang mengikuti pelajaran, dapat menemukan kesulitan belajar karena adanya daya tarik yang diperoleh dengan mata pelajaran PPKn. Proses belajar akan berjalan dengan baik jika disertai dengan minat belajar siswa yang tinggi.

Salah satu faktor psikologis yang turut menentukan keberhasilan didalam pembelajaran adalah minat belajar siswa. Kurangnya rasa ketertarikan pada suatu bidang tertentu, akan melahirkan sikap 
penolakan terhadap guru. Dari uraian di atas, guru mempunyai peran yang sangat penting dalam meningkatkan motivasi belajar siswa yang termasuk rasa ketertarikan siswa terhadap bidang tertentu. Secara konseptual,peran guru dalam proses pembelajaran meliputi banyak hal antara lain sebagai model,manajer

kelas,mediator,komunikasi,fasilitator dan evaluator.Akan tetapi kini guru hanya dipahami sebagai tenaga pengajar semata.semantara peran-peran yang lainnya agaknya tercampakan.Adanya interverensi pemerintah yang berlebiahan dalam pendidikan juga semakin menambah parah kondisi tersebut. Salah satunya ialah tuntunan untuk mengajar sesuai target kurikulum yang berlaku. Hal ini akan mengakibatkan minat bakat kemampuan dan potensi-potensi yang dimiliki oleh peserta didik tidak akan berkembang secara optimal tanpa adanya bantuan seorang guru. Berdasarkan kondisi demikian, penulis tertarik untuk melakukan sebuah penelitian yang berjudul "Profesionalisme Guru PPKn untuk Meningkatkan Motivasi Belajar Siswa".

\section{METODE PENELITIAN}

Metode yang digunakan dalam penelitian "Profesionalisme Guru PPKn Untuk Meningkatkan Motivasi Belajar Siswa" menggunakan metode kulitatif deskriftif. Metode penelitian kualitatif adalah metode penelitian yang berlandaskan pada filsafat postpositivisme, digunakan untuk meneliti pada kondisi objek yang alamiah. (sebagai lawannya adalah eksperimen) dimana peneliti adalah sebagai instrument kunci, teknik pengumpulan data dilakukan secara gabungan, analisis data bersifat induktif/kualitatif, dan hasil penlitian kualitatif lebih menekankan makna dari pada generalisasi.(Sugiono, 2015, hlm.09) Berdasarkan pendapat yang telah dipaparkan diatas, maka penelitian ini berupaya untuk memusatkan perhatian kepada profesionalisme guru PPKn di MTs Al-Khairiyah Pipita. Dengan jenis penelitian deskriptif kualitataif berarti menggambarkan seperti apa profesionalisme guru PPKn dalam meningkatkan Motivasi belajar siswa kelas VII D MTs Al-Khairiyah Pipitan yang hasilnya akan dijabarkan secara deskriptif analisis. Dalam penelitian ini, peneliti menggunakan teknik pengumpulan data observasi, wawancara, dan dokumentasi. 
Observasi ini di lakukan dilingkungan MTs Al-Khairiyah Pipitan dengan melakukan kunjungan dan melihat kondisi di dalamnya. Dalam hal ini peneliti menggunakan teknik observasi partisipatif, dimana peneleliti ikut terjun langsung dan terlibat dengan kegiatan sehari-hari orang yang sedang diamati atau yang digunakan sebagai sumber data penelitian. Nasution (1988) menyatakan bahwa, observasi adalah dasar semua ilmu pengetahuan. Para ilmuwan hanya dapat bekerja berdasarkan data, yaitu fakta mengenai dunia kenyataan yang diperoleh melalui obsevasi. Selain itu, peneliti mengunakan teknik wawancara terstruktur karena dalam melakukan wawancara, selain harus membawa instrument sebagai pedoman untuk wawancara, maka pengumpulan data juga dapat mengunakan alat bantu seperti tape recorder, gambar, brosur dan matrial lain yang dapat membantu pelaksanaan wawancara menjadi lancar, dengan narasumber guru dan siswa/siswi kelas VII D MTs Al-Khairiyah Pipitan.

Dan yang terakhir peneliti menggunakan teknik dokumentasi. Dokumentasi merupakan catatan peristiwa yang sudah berlalu. Dokumen yang digunakan dalam penelitian dapat berupa tulisan, gambar, atau sebuah karya-karya monumental.
Oleh karena itu dalam setiap penelitian tidak pernah dapat dilepaskan dari linteratur-linteratur ilmia sehingga kegiatan studi kepustakaan ini menjadi sangat penting. Analisis data dalam penelitian kualitatif dilakukan sejak sebelum memasuki lapangan dan selama di lapangan. Langkah-langkah dalam menganalisis data pada penelitian kualitatif deskriptif yaitu mengacu pada langkah-langkah yang dikemukakan oleh Miles and Huberman dalam Sugiyono (2015:246) adalah:

1. Reduksi data

2. Display data

3. Verification (penyimpulan data)

\section{HASIL PENELITIAN DAN} PEMBAHASAN

Seorang guru bertanggung jawab terhadap keberhasilan belajar peserta didiknya. Di samping itu, sebagai seorang yang profesional guru mempunyai tanggung jawab atas hasil kinerjanya, kepada Yang Maha Kuasa, pemerintah, lembaga internal, masyarakat dan kepada orang tua peserta didik, bahkan bertanggung jawab pula terhadap peserta didik itu sendiri.

Berdasrkan pernyataan diatas bahwa profesionalisme guru adalah guru harus memiliki keahlian kusus yang telah guru miliki dari pendidikan yang mereka 
dapatkan. Untuk menjadi guru yang profesional maka guru harus memiliki kemampuan dan keahlian dalam bidang keguruan, sehingga ia mampu melaksanakan tugasnya dengan maksimal. Penekanan terhadap profesional cenderung untuk memelihara dan mengikuti setandar etika yang berlaku di dalam masyarakat. Bertolak dari keterangan diatas menunjukkan bahwa pelakasanaan dan penerapan guru profesional di MTs Al-Khairiyah Pipitan khususnya guru PPKn, masih ada guru yang berlatar belakang bukan dari mata pelajaran yang ia ampuh di sekolah tersebuat, tetapi dari latar belakang yang berbedah terebuat bukan menjadi alasan guru tersebuat bekerja atau menjalankan tugasnya tidak profesional. Dengan kata lain pelaksanaan dalam proses pengajaran di MTs Al-Khairiyah Pipitan sudah berjalan dengan baik dan lancar. Dikatakan baik dan lancar karena guru yang bersangkutan sudah memiliki dan mendapatan sertifikasi keguruan dan memperdalam ilmu PPKn dengan mencari bahan-bahan materi yang ada di sekolah tersebut, serta berbagi ilmu dengan rekan sesama guru guna menambah pengetahuan dalam ilmu PPKn. Pemahaman terhadap perkembangan peserta didik sangat diperlukan untuk merancang pembelajaran yang kondusif yang akan dilaksanakan.

Guru yang mampu mengenal dan memahami peserta didiknya, akan lebih mudah mengarahkan dan mengendalikan situasi kelasnya. Tidak ada hal yang tidak mungkin kita lakukan, tekad dan kemauan akan mematakan hal yang tidak mungkin terjadi menjadi hal yang bisa terjadi. Bertolak dari keterangan diatas menunjukkan bahwa pelakasanaan dan penerapan guru profesional dalam hal memiliki kemampuan memahami peserta didik di MTs Al-Khairiyah Pipitan khususnya guru PPKn sudah memiliki kemampuan di dalam memahami kemampuan peserta didiknya dengan cara memberikan pelayanan terhadap perbedaan individu siswa, hal ini akan bermakna manakala mendapat pelayanan yang optimal dari tenaga pendidik dan peserta didik mendapatkan kesempatan mengembangkan diri sesuai dengan kemampuan yang mereka miliki. Mengelola pembelajaran penilaian dengan bermutu adalah tugas pendidik dan satuan pendidikan. Dengan melakukan pembelajaran dan penilaian, pendidik akan mampu menjalankan fungsi penilaian yakni untuk mengukur dan menilai tingkat pencapian kompetensi peserta didik serta mendeskripsikan 
capaian hasil pembelajaran peserta didik. Kemampuan guru dalam melaksanakan penilaian sangat penting karena memepengaruhi bagaimana hasil penilaian dan proses evaluasi. Dimana proses penilaian merupakan salah satu faktor dalam mendukung berhasilnya sebuah proses dan hasil pembelajaran. Guru sebagai pelaku atau pelaksana dalam penilaian tentunya punya andil yang sangat besar dalam pelaksanaan penilaian yang baik. Bertolak dari keterangan diatas menunjukkan bahwa pelakasanaan dan penerapan guru profesional dalam hal Menyusun Perangkat Penilaian Hasil Belajar dan Proses Pembelajaran di MTs Al-Khairiyah Pipitan khususnya guru PPKn sudah dilakukan dengan baik tujuannya agar siswa bisa termotivasi dengan mendapatkan nilai yang mereka dapatkan dari guru. Dalam proses belajar mengajar di MTs Al-Khairiyah Pipitan upaya yang pertama dilakukan oleh guru PPKn tidak lain adalah berusaha merangsang dan membangkitkan motivasi belajar siswa agar mereka dapat belajar dengan optimal dan berkonsentrasi. Tidak akan terwujud apabila siswa tidak termotivasi. Motivasi dapat dikatakan sebagai keseluruahan daya penggerak di dalam diri siswa yang menimbulkan kegiatan belajar, yang menjamin kelangsungan dari kegiatan belajar dan yang memberikan arah pada kegiatan belajar, sehingga tujuan yang dikehendaki oleh subjek belajar itu tercapai. (Sardiman, 2014, hlm.75). Motivasi belajar penting bagi siswa dan guru. Bagi siswa motivasi belajar itu penting untuk menyadarkan kedudukan awal belajar, proses dan hasil akhir, menginformasikan tentang kekuatan usaha belajar, mengarahkan kegiatan serta menambah semangat belajar. Motivasi belajar juga penting diketahui oleh guru. Pengetahuan dan pemahaman tentang motivasi belajar pada siswa bermanfahat bagi guru, yaitu membangkitkan, meningkatkan, dan memelihara semangat siswa untuk belajar sampai ahkir. Dalam proses pembelajaran tentu tidak luput dari berbagai problem atau masalah yang dihadapi, sebab setiap guru mempunyai masalah yang dihadapi baik yang datang dari dalam maupun dari luar. Masalah tersebut bisa saja datang dari peserta didik atau murid, baik masalah kemampuan peserta didik itu sendiri atau minat siswa terhadap mata pelajaran yang diajarakan oleh gurunya itu sendiri. Dalam proses pembelajaran tidak semua berjalan dengan baik, seorang guru yang profesional sekalipun pasti akan menemukan berbagai kendala dalam belajar mengajar pada peserta didiknya. 
Salah satu kendala yang sering dijumpai pada proses pembelajaran ialah kurang termotivasinya siswa. Bagi siswa dalam proses belajar mengajar, tentu akan sulit meraih keberhasilan apabila tidak mendapat dorongan dengan baik. Oleh karena itu, hendaknya seorang guru memepunyai cara dalam membangun hubungan kepada siswanya. Persoalan motivasi dapat juga dikaitkan dengan persoalan minat. Minat merupakan suatu kondisi yang dihubungkan dengan keinginan atau kebutuhannya. Oleh karena itu, apa yang dilihat seseorang sudah tentu akan membangkitkan minatnya sejauh apa yang dilihat itu mempunyai hubungan dengan kepentingannya sendiri. Hal ini menunjukan bahwa minat merupakan sebuah kecenderungan jiwa seseorang kepada suatu hal yang disertai perasaan senang, dengan hal itu merasa adanya kepentingan atau kebutuhan terhadap sesuatu itu.

Banyak cara yang dapat digunakan sebagai upaya untuk meningkatkan motivasi belajar, karena motivasi merupakan suatu proses psikologis yang mencerminkan sikap. Sardiman A.M ( 2014:92-95 ) menjelaskan ada beberapa bentuk dan cara untuk menumbuhkan motivasi dalam kegiatan belajar :

\section{Memberikan angka}

Angka yang dimaksud adalah simbol nilai dalam kegiatan belajarnya. Banyak siswa belajar, yang utama justru untuk mencapai angka/nilai yang baik. Sehingga siswa biasanya yang dikejar adalah nilai ulangan atau nilai-nilai raport angkanya baik-baik. Memperoleh angka yang baik dan tinggi merupakan motivasi yang sangat kuat bagi seorang siswa. Tetapi ada juga, bahkan banyak siswa bekerja atau belajar hanya ingin mengejar pokonya naik kelas saja. Ini menujukan motivasi yang dimilikinya kurang berbobot bila dibandingkan dengan siswa-siswa yang mengingkinkan angka baik. Namun, dalam hal ini harus menjadi perhatian bagi seorang guru bahwa pencapaian angka yang tinggi bukanlah hasil belajar yang sejati, bukan hasil belajar yang bermakna.

Namun demikian semua itu harus diingat oleh guru bahwa pencapaian angka-angka seperti itu belum merupakan hasil belajar yang sejati, hasil belajar yang bermakna. Oleh karena itu, langkah selanjutnya yang ditempuh oleh guru adalah bagai mana cara memberikan angka-angka dapat dikaitkan dengan values yang terkandung di dalam setiap pengetahuan yang diajarkan kepada para siswa sehingga 
tidak sekedar kognitif saja tetapi keterampilan dan afeksinya.

2. Hadiah

Hadiah dapat juga dikatakan sebagai motivasi,tetapi tidaklah selalu dipikirkan. Karena hadiah untuk suatu pekerjaan, mungkin tidak akan menarik bagi seseorang yang tidak senang dan tidak berbakat untuk sesuatu pekerjaan tersebut. Sebagai contoh hadiah yang diberikan untuk gambar yang terbaik mungkin tidak akan menarik bagi seorang siswa yang tidak memiliki bakat menggambar.

\section{Saingan/kompetisi}

Persaiangan atau kompetisi dalam kegiata belajar dapat dijadikan sebagai alat motivasi siswa untuk mendorong belajar siswa. Hal ini dapat meningkatkan prestasi belajar siswa.

4. Memberi ulangan

Para siswa akan giat belajat kalau mengetahui aka nada ulangan. Oleh karena itu, memberikan ulangan ini juga merupakan sarana motivasi. Tetapi yang harus diingat oleh guru, adalah jangan terlalu sering (misalnya setiap hari) karena bisa membosankan dan sifat rutintis. Dalam hal ini guru harus juga terbuka, maksudnya kalau akan ulangan harus diberitahukan kepada siswanya.

\section{KESIMPULAN}

Berdasarkan pada temuan data di lapangan dan sebagaimana dipaparkan dalam bab-bab terdahulu maka dapat diambil beberapa kesimpulan berkenaan dengan rumusan masalah yang diangkat dalam penelitian ini. Hal-hal tersebut sebagai berikut :

1. Profesionalisme guru PPKn dalam meningkatkan motivasi belajar siswa kelas VII D di MTs Al-Khairiyah Pipitan sudah menunjukan profesionalismenya sebagai guru PPKn di MTs tersebuat karena guru tersebut telah memiliki sertifikasi keguruan dan juga telah dibuktikan dengan indicator/faktor sebagai berikut:

- Memiliki keahlian khusus yang dipersiapkan oleh program pendidikan keahlian atau spesialisasi.

- Memiliki kemampuan memahami peserta didik.

- Kemampuan menyusun perangkat penilaian hasil belajar dan proses pembelajaran.

2. Hambatan guru dalam memberikan motivasi belajar siswa kelas VII D di MTs Al-Khairiyah Pipitan disebabkan oleh faktor internal dan 
eksternal dari dalam diri siswa. Faktor internal dalam penelitian ini adalah tingkat pemahaman siswa yang berbeda-beda. Sedangkan fakator eksternalnya adalah faktor dari orang tua dan lingkungan pergaulan dan masyarakat disekitar siswa. . Sala satu kendala yang sering dijumpai pada proses pembelajaran ialah kurang termotivasinya siswa. Bagi siswa dalam proses belajar mengajar, tentu akan sulit meraih keberhasilan apabila tidak mendapat dorongan dengan baik. Oleh karena itu, hendaknya seorang guru memepunyai cara dalam membangun hubungan kepada siswanya.

3. Solusi guru dalam memberikan motivasi belajar siswa kelas VII D di MTs Al-Khairiyah Pipitan ialah dengan cara guru memberikan stimulus kepada siswa, memberikan motivasi agar anak didiknya melakukan aktifitas belajar dengan baik. Keberhasilan dalam proses pembelajaran salah satunya dipengaruhi oleh motivasi belajar siswa. Dalam hal ini, guru dituntut memiliki kreativitas untuk dapat meningkatkan motivasi belajar siswa. Peran guru sangat penting, bagaimana guru melakukan usaha- usaha untuk dapat menumbuhkan dan memberikan motivasi agar anak didiknya melakukan aktifitas belajar dengan baik. Untuk dapat belajar dengan baik.

\section{DAFTAR PUSTAKA}

\section{Buku:}

Dalyono, M. (2012). Psikologi Pendidikan. Jakarta:Rineka Cipta Djamarah, Syaiful Bahri (2011). Psikologi belajar Cet.01: Jakarta ; CV. Rineka Cipta

Mohammad Daud Ali.\& Habibah Daud (2019). Lembaga-Lembaga Islam di Indonesia Cet.1:Jakarta; PT. Raja Grafindo Persada

Nasution, S. 1988. Metode Penelitian Naturalistik Kualitatif. Tarsito. Bandung Tarsito.

Sardiman A.M. (2014). Interaksi\&Motivasi Belajar Mengajar Cet.22: Jakarta; PT. Raja Grafindo Persada

Sugiyono. (2014). Metode penelitian kualitatif dan $R \& D$. Bandung: Alfabeta.

Usman, Moch. Uzer. 2014. Menjadi Guru Profesional. Bandung: PT Remaja Rosdakarya 